\title{
Acrocarpus fraxinifolius Wight and Arn. Bark; phenolics, toxicity studies, antioxidant and anti-inflammatory activities
}

\author{
Aisha Hussein Abou Zeid ${ }^{1 *}$, Reda Sayed Mohammed ${ }^{1 *}$, \\ Amal Abdelrasheed Maamoun', Amany Ameen Sleem² \\ ${ }^{1}$ Pharmacognosy Dept., Cairo, Egypt, ${ }^{2}$ Pharmacology Dept., National Research \\ Centre. Cairo, Egypt
}

\begin{abstract}
The purpose of the survey was to determine acute \& chronic toxicity; in vivo antioxidant and antiinflammatory actions of the different extracts of A. fraxinifolius Wight and Arn bark; along with estimation of the phenolic, flavonoidal contents and investigation of phenolic metabolites that may attribute to the activities. $\mathrm{LD}_{50}$ of the total ethanol extract (TEE) was $7.1 \mathrm{~g} / \mathrm{kg} \mathrm{b}$. wt, the radical scavenging activity of DPPH showed $60.31 \%$ inhibition, FRAP ability and ABTS $^{+}$activity showed 55.024 and $67.217 \mu \mathrm{mol}$ Trolox/100 g dry weight, respectively. TEE followed by ethyl acetate extract (EAE) at $100 \mathrm{mg} / \mathrm{kg}$ b.w exhibited the highest in vivo antioxidant activity $(94.51 \%$ and $91.08 \%$ potency, respectively) compared with Vit E (100\%). The TEE \& EAE exhibited the highest anti-inflammatory activity $(3.81 \pm 0.08 \& 3.79 \pm .0 .04)$ respectively in comparison with indomethacin $3.83 \pm 0.01$ measured as edema diameter after 4 hours of extract administration. The total phenolic and total flavonoid contents in the total ethanol extract (TEE) estimated as gallic acid and catechin equivalents were $61.06 \pm 0.08 \mu \mathrm{g}$ eq GA/g, 40.33 $\pm 0.20 \mu \mathrm{g} \mathrm{CE} / \mathrm{g}$ extract respectively. EAE revealed five phenolic acids and eight flavonoid compounds isolated for the first time from the plant.
\end{abstract}

Keywords: Acrocarpus fraxinifolius. Chronic toxicity. antioxidant. Anti-inflammatory activities. Phenolics.

\section{INTRODUCTION}

A. fraxinifolius commonly known as mundane and shingle tree. It is a native spread around the world, especially in Africa and Asia (V'azquez et al. 1987). Pink cedar, mundane, and lazcar are common names of $A$. fraxinifolius. It is well known that the bark of any plant provides protection of the tree, structural support, and leads nutrients from the leaves to the roots, it acts as a physical and chemical barrier against microorganisms, chemically the bark has the same constituents of wood such as terpenes, polyphenols, and nitrogen containing

*Correspondence: R. S. Mohammed. Pharmacognosy Dept.. National Research Centre. 33 El-Bohouth., Dokki, Giza, Egypt, P.O.12622 (ID: 60014618)., Dokki - Giza-Egypt. P.O.12622, ID: 60014618. E-mail: redamohammed2015@gmail.com. A. H. Abou Zeid. Pharmacognosy Dept.. National Research Centre. 33 El-Bohouth., Dokki, Giza, Egypt, P.O.12622 (ID: 60014618). Dokki - Giza-Egypt. P.O.12622, ID: 60014618. E-mail: abouzeida@yahoo.co.uk compounds. The variation of phenolic contents of older and younger tree of the plant barks together with its in vitro antioxidant activities was reported (et al., 2015). Considering the previous reported work for investigation of phenolics, lipoidal contents along with different biological activities of $A$. fraxinifolius (Abou Zeid et al., 2011, 2012); as well as phenolic, tannins, flavonoids, in vivo hepatoprotective, antiproliferatives, antioxidant and antimicrobial activities of $A$. fraxinifolius leaves were studied (El-Nashar et al., 2017; Walaa et al., 2016). A flavone glycoside was isolated from the seeds (Bardia et al., 2005) of A. fraxinifolius which was subjected to amino acid analysis (Bardia, Rao 2004a, b). Galactomannans from the seeds were isolated and characterized by IR spectrophotometry (Zhong, 1985). In this work we propose to yield deep insight on the phytoconstituents of A. fraxinifolius bark as antioxidant\& anti-inflammatory active agent 


\section{MATERIAL AND METHODS}

\section{Experimental}

The structure of the compounds was identified by spectroscopic methods including: UV/VIS (Ultraviolet and Visible Absorption Spectrometer, Labomed Inc.) for measuring UV spectral data of the isolated compounds, in the range of 200-500 NM in methanol and with different diagnostic shift reagents. NMR (Nuclear Magnetic Resonance Spectrophotometer, JEOL EX, 500 $\mathrm{MHz}$ for determination of ${ }^{1} \mathrm{H}-\mathrm{NM}$ Rand $125 \mathrm{MHz}$ for determination of $\left.{ }^{13} \mathrm{C}-\mathrm{NMR}\right)$. Column chromatography (CC) was carried out on Flash CC $(24 \mathrm{~cm}$ long, $10 \mathrm{~cm}$ diameter) packed with $100 \mathrm{~g}$ silica gel (H20 for plate). Sephadex LH-20 (Pharmazia) for purification of the isolated compounds. PC (descending) Whatman No. 1 and $3 \mathrm{MM}$ papers, $15 \% \mathrm{HOAc}-\mathrm{H}_{2} \mathrm{O}$, BAW (n-BuOH: HOAc: $\mathrm{H}_{2} \mathrm{O}$ 4:1:5, upper layer). Complete acid hydrolysis for $\mathrm{O}$-glycosides was carried out \& followed by $\mathrm{Co}-$ chromatograph with authentic samples to identify the aglycones and sugar moieties. Source of solvents used for plant extraction: SDFCL(Industrial Estate, 248 Worli Road, Mumbai-30, India).Vitamin E (dl $\alpha$-tocopheryl acetate) (Pharco Pharmaceutical Co), it is available in the form of gelatinous capsules; each contains $400 \mathrm{mg}$ vitamin E. As a reference drug for in-vivo antioxidant test. Alloxan (Sigma Co) was used for the induction of free radical in -vivo antioxidant. Carrageenan, Sigma Co. For induction of acute inflammation in rat, Indomethacin (Indocid), Kahira Pharm. IND. Co. A.R.E. As a standard anti-inflammatory agent.

\section{Plant material}

The leaves and bark of $A$. fraxinifolius Wight \& Arn were collected in April 2008 from the Giza Zoo. The plant was identified by Mrs. Terase Labib, plant taxonomist of Orman Garden, Giza, Egypt and confirmed by the senior taxonomist, Dr. M. El-Gebaly. The plant was air-dried, powdered and kept in well-closed, dark colored containers in a cold place. A voucher specimen (M96) has been deposited by Dr. Mona Marzouk in the Herbarium of National Research Centre (CAIRC).

\section{Preparation of total ethanol extract (TEE)}

One $\mathrm{kg}$ of the powdered plant under investigation was extracted by $70 \%$ ethanol in a continuous extraction apparatus. After complete extraction, the solvent was evaporated under vacuum at $40{ }^{\circ} \mathrm{C}$ (and the residue was weighed.

\section{Preparation of successive extracts}

One $\mathrm{kg}$ of the powdered plant was successively extracted in a continuous extraction apparatus, with the following successive solvents with increasing polarities: petroleum ether (PE), chloroform (Ch), ethyl acetate (EA) and methanol (M). After each complete extraction with one solvent, the powdered plant was dried and extracted with the next solvent. All extracts were separately evaporated to dryness and weighed.

\section{Determination of total phenolic content (TPhC)}

The total phenolic content of the total ethanol extract was determined according to the reported FolinCiocalteu method (Abou Zeid et al., 2015). Briefly, the extract $(500 \mu \mathrm{L})$ was transferred into a test tube and oxidized with the addition of $250 \mu \mathrm{L}$ of Folin-Ciocalteau reagent. After $5 \mathrm{~min}$, the mixture was neutralized with $1.25 \mathrm{~mL}$ of $20 \%$ aqueous $\mathrm{Na}_{2} \mathrm{CO}_{3}$ solution left for 40 min, the absorbance was measured at $725 \mathrm{~nm}$ against the solvent blank. The total phenolic content was determined by means of a calibration curve prepared with gallic, and expressed as $\mu \mathrm{g}$ of gallic acid equivalent (GAE) per $\mathrm{mL}$ of sample.

\section{Determination of total flavonoid content (TFC)}

The total flavonoidal content of the total ethanol extract was determined as reported (Abou Zeid et al., 2015). Briefly, $250 \mu \mathrm{L}$ of $5 \% \mathrm{NaNO}_{2}$ was mixed with $500 \mu \mathrm{L}$ of extract. After $6 \mathrm{~min}, 2.5 \mathrm{~mL}$ of a $10 \% \mathrm{AlCl}_{3}$ solution was added. After $7 \mathrm{~min}, 1.25 \mathrm{~mL}$ of $1 \mathrm{M} \mathrm{NaOH}$ was added, and the mixture was centrifuged at $5000 \mathrm{~g}$ for $10 \mathrm{~min}$. Absorbance of the supernatant was measured at $510 \mathrm{~nm}$ against the solvent blank. The total flavonoid content was expressed as $\mu \mathrm{g}$ of catechin equivalent (CE) per $\mathrm{mL}$ of sample.

\section{Column chromatographic isolation and purification}

Twenty five grams of the EAE were fractionated by flash CC ( $24 \mathrm{~cm}$ length, $10 \mathrm{~cm}$ diameter) packed with $100 \mathrm{~g}$ silica gel $\mathrm{H} 20$ for the plate. The extract was eluted with chloroform $100 \%$ and increasing polarity with ethyl 
acetate till $100 \%$ EA then increasing the polarity with methanol till $100 \%$ methano. A fraction of $500 \mathrm{~mL}$ was collected, inspected on whatman no 1 MM PC. Similar fraction were collected to give 10 major fractions (F-1 : F-10) they were then subjected to different chromatographic techniques including $3 \mathrm{MM}$ preparative paper chromatography and repeated Sephadex LH20 column using eluents of different polarities this led to the isolation and purification of thirteen phenolic compounds (1-13). The final purification of all compounds was achieved by Sephadex LH20 column using $\mathrm{MeOH}$ as eluent. The isolated compounds from the bioactive EAE of $A$. fraxinifolius bark was structurally elucidated through $\mathrm{R}_{\mathrm{f}}$ values, color reactions, chemical investigations (complete acid hydrolysis) and spectral investigations (UV, NMR and MS) (Mabry et al., 1970; Markham 1982; Agrawal 1989).

\section{Biological study}

\section{In vitro antioxidant activity}

Antioxidant activity means the ability of compounds to prevent damage from reactive oxygen species (ROS) or to prevent their generation (Ku"hnau 1976). ROS and Reactive nitrogen species (RNS) are major sources of oxidative stress in cells, damaging proteins, lipids, and DNA (Orrenius et al,).Therefore, prevention of oxidative stress caused by ROS and RNS has important effect for the prevention and treatment of disease (Mohammed et al., 2014).

\section{Determination of DPPH radical scavenging activity}

DPPH is a stable nitrogenous free radical compound, the color of which changes from violet to yellow upon reduction by either the process of hydrogen capture or electron donation. Substances which are able to perform this reaction can be considered as antioxidants and therefore radical scavengers (Ebrahimzadeh et al., 2009b; Nabavi et al., 2008). Free radical scavenging capacity was determined using the stable 1,1-diphenyl2-picryl-hydrazyl (DPPH•). The final concentration was $50 \mu \mathrm{M}$ for $\mathrm{DPPH} \bullet$ and the final reaction volume was $3.0 \mathrm{~mL}$. The absorbance at $517 \mathrm{~nm}$ was measured against a blank of pure methanol $60 \mathrm{~min}$. Percent inhibition of the DPPH free radical was calculated by the following equation: \% Scavenging $=[(\mathrm{A}$ control-A sample $) /$ Acontrol] $\times 100$
Where: A control is the absorbance of the control reaction

A sample is the absorbance of the test compound.

\section{Determination of ferric reducing antioxidant power (FRAP)}

The test was used to measure the total antioxidant capacity method based on the reduction of a ferric-tri pyridyltriazine complex to its ferrous colored form in the presence of antioxidants. It is regarded as accurate indicators of total antioxidant power, since total reducing power is defined as the sum of the reducing powers of the individual compounds contained in a particular sample (Tezcan et al., 2011).

The stock solutions included $300 \mathrm{mM}$ acetate buffer, pH 3.6, $10 \mathrm{mM}$ TPTZ (2, 4, 6-tripyridyl-striazine) solution in $40 \mathrm{mM} \mathrm{HCl}$, and $20 \mathrm{mM} \mathrm{FeCl}_{3} \cdot 6 \mathrm{H}_{2} \mathrm{O}$ solution. The fresh working solution was prepared by mixing $25 \mathrm{~mL}$ acetate buffer, $2.5 \mathrm{~mL}$ TPTZ solution, and $2.5 \mathrm{~mL} \mathrm{FeCl} \cdot 6 \mathrm{H}_{2} \mathrm{O}$ solution and then warmed at $37{ }^{\circ} \mathrm{C}$ before using. The extract was allowed to react with $2850 \mu \mathrm{L}$ of the FRAP solution for $30 \mathrm{~min}$ in the dark condition. Readings of the colored product (ferrous tripyridyltriazine complex) were then taken at $593 \mathrm{~nm}$. Results are expressed in $\mu \mathrm{mol}$ Trolox/g dry matter. Additional dilution was needed if the FRAP value measured was over the linear range of the standard curve. A compound exhibiting a positive result in the FRAP assay was an electron donor and it terminated the oxidation chain reaction by reducing the oxidized intermediates into the stable form (Suganya 2007).

\section{Determination of ABTS radical scavenging activity:}

The stock solutions included, $7 \mathrm{~m}$ M ABTS solution and $2.4 \mathrm{mM}$ potassium persulfate solution. The working solution was then prepared by mixing the two stock solutions in equal quantities and allowing them to react for 12 hours at room temperature in the dark. The solution was then diluted by mixing $1 \mathrm{~mL} \mathrm{ABTS} .^{+}$solution with $60 \mathrm{~mL}$ methanol to obtain an absorbance of $0.706 \pm$ 0.001 units at $734 \mathrm{~nm}$ using the spectrophotometer. ABTS. ${ }^{+}$Solution was freshly prepared for each assay. Plant extract $(0.5 \mathrm{~mL})$ was allowed to react with $3 \mathrm{~mL}$ of the ABTS. ${ }^{+}$solution and the absorbance were taken at $734 \mathrm{~nm}$ after $7 \mathrm{~min}$ using the spectrophotometer. Results are expressed in $\mu \mathrm{mol}$ Trolox/g dry matter 
Each of the above assays was carried out in triplicate. The previous antioxidant activities were carried out according to the reported methods (Mohammed et al., 2015).

\section{In vivo biological study: Experimental animals}

Adult albino rats, of Sprauge Dawely Strain weighing 130-150 g and Albino mice weighing 2530g. Animals were obtained from the animal house colony of the National Research Centre, Dokki, Egypt. They were kept under the same hygienic conditions and well-balanced diet and water. Medical Research Ethical Committee (MREC) in the National Research Centre has approved the work (15 - 101). All animals were kept at normal diet consists of vitamin mixture $1 \%$, mineral mixture $4 \%$, corn oil $10 \%$, sucrose $20 \%$, cellulose $0.2 \%$, casein (95\% pure) $10.5 \%$ and starch $54.3 \%$. The Doses of the drugs were calculated and were administered orally by a gastric tube (Abou Zeid et al., 2009).

\section{Acute toxicity test: Determination of Median Lethal Dose (LD50) Paget and Barnes 1964}

Male albino mice were divided into groups, each of six animals. Preliminary experiments were undertaken to determine the minimal dose that kills all animals $\left(\mathrm{LD}_{100}\right)$ and the maximal dose that fails to kill any animal. Several doses at equal logarithmic intervals were chosen in-between these two doses, and each dose was injected into a group of six animals by subcutaneous injection. The mice were observed for 24 hours, symptoms of toxicity and mortality rates in each group were recorded, and $\mathrm{LD}_{50}$ was calculated.

\section{Chronic toxicity test: Effect on the body and internal organ weights}

Male albino rats were divided into two groups of 12 animals each. Rats of first group received 1 mal saline and second groups were administered TEE of $A$. fraxinifolius bark $100 \mathrm{mg} / \mathrm{kg}$ for 8 weeks. Body weights of rats were recorded at zero, 4,8 at the end of the experimental period (8 weeks), animals were sacrificed and their internal organs, including kidney, heart, lung, spleen liver tests and seminal vesicles were dissected off, then investigated for any morphological changes and accurately weighed. The results were illustrated in Tables I and II.
TABLE (I) - Effect of long term administration of daily oral dose $(100 \mathrm{mg} / \mathrm{kg} \mathrm{B}$. wt.) of TEE of $A$. fraxinifolius bark on body weight in male albino rats

\begin{tabular}{lccc}
\hline \multirow{2}{*}{ Group } & \multicolumn{3}{c}{ Body weight (gm) } \\
\cline { 2 - 4 } & $\begin{array}{c}\text { Zero time (before } \\
\text { treatment) }\end{array}$ & $\mathbf{4}$ weeks & $\mathbf{8}$ weeks \\
\hline Control & $130.9 \pm 3.9$ & $166.1 \pm 5.6^{*}$ & $187.2 \pm 7.6^{*}$ \\
TEE. & $132.8 \pm 3.4$ & $158.2 \pm 6.1^{*}$ & $186.1 \pm 8.6^{*}$ \\
\hline
\end{tabular}

* Statistically significant from zero time at $\mathrm{p}<0.01$.

TABLE (II) - Relative organs weights of male rats treated with daily oral dose $(100 \mathrm{mg} / \mathrm{kg}$ b.wt of TEE of $A$. fraxinifolius bark extract for 8 weeks

\begin{tabular}{lcc}
\hline \multirow{2}{*}{ Organs } & \multicolumn{2}{c}{ Relative organ weight (g/100 g B.wt). } \\
& Control & TEE \\
\cline { 2 - 3 } Kidney & $0.95 \pm 0.03$ & $0.91 \pm 0.6$ \\
Heart & $0.57 \pm 0.09$ & $0.66 \pm 0.04$ \\
Lungs & $0.81 \pm 0.05$ & $0.91 \pm 0.24$ \\
Spleen & $0.43 \pm 0.09$ & $0.46 \pm 0.09$ \\
Liver & $3.90 \pm 0.03$ & $4.08 \pm 0.30$ \\
Tests & $1.50 \pm 0.02$ & $1.8 \pm 0.07$ \\
Seminal vesicles & $0.45 \pm 0.04$ & $0.48 \pm 0.01$ \\
\hline
\end{tabular}

TEE: Total ethanol extract

\section{Effect on biochemical parameters}

Twelve male albino rats were divided into two groups of six rats. The first group kept as a control group and received $1 \mathrm{~mL}$ saline as a daily dose. The second received daily oral doses of $100 \mathrm{mg} / \mathrm{kg}$ b.wt. of the total ethanol extract of $A$. fraxinifolius bark for 8 weeks. Blood samples were obtained at zero time, 4 and 8 weeks from the retro orbital venous plexus of each rat, collected in clean tubes. Serum was isolated by centrifugation and divided for analysis of cholesterol Abou Zeid et al 2009, triglycerides, blood glucose level, creatinine, blood urea, Aspartate aminotrasferase (AST/GOT), and alanine aminotransferase ALT/GPT (Allian et al., 1974). Results are illustrated in Table III. 
TABLE (III) - Effect of long term administration of TEE of A. fraxinifolius bark on cholesterol, triglycerides, glucose, creatinine, blood urea and liver enzymes (AST and ALT) serum levels in male albino rats $(\mathrm{n}=6)$

\begin{tabular}{|c|c|c|c|c|c|c|c|c|}
\hline \multirow{2}{*}{$\begin{array}{l}\text { Group } \\
\text { Control }\end{array}$} & \multirow{2}{*}{$\begin{array}{l}\text { Time in } \\
\text { weeks }\end{array}$} & \multicolumn{7}{|c|}{ Biochemical changes of serum levels } \\
\hline & & $\begin{array}{c}\text { Cholesterol } \\
\text { mg/dL }\end{array}$ & $\begin{array}{c}\text { Triglycarides } \\
\text { mg/dL }\end{array}$ & $\begin{array}{l}\text { Glucose } \\
\mathbf{m g} / \mathbf{d L}\end{array}$ & $\begin{array}{c}\text { Creatinine } \\
\text { mg/dL }\end{array}$ & $\begin{array}{l}\text { Urea mg/ } \\
\text { dL }\end{array}$ & AST U/L & ALT U/L \\
\hline \multirow{3}{*}{ (1 mL saline) } & Zero time & $92.1 \pm 6.5$ & $79.9 \pm 3.9$ & $86.3 \pm 5.1$ & $1.40 \pm 0.1$ & $21.3 \pm 0.3$ & $45.1 \pm 1.5$ & $32.8 \pm 1.5$ \\
\hline & 4 weeks & $90.2 \pm 8.6$ & $77.2 \pm 6.1$ & $89.6 \pm 4.7$ & $1.42 \pm 0.2$ & $22.1 \pm 1.7$ & $43.2 \pm 1.3$ & $32.4 \pm 1.3$ \\
\hline & 8 weeks & $89.5 \pm 3.3$ & $81.9 \pm 5.8$ & $81.1 \pm 4.7$ & $1.45 \pm 0.2$ & $23.3 \pm 1.3$ & $44.3 \pm 1.8$ & $34.8 \pm 1.8$ \\
\hline \multirow{3}{*}{$\begin{array}{l}\text { Total ext. } \\
100 \mathrm{mg} / \mathrm{kg}\end{array}$} & Zero time & $88.6 \pm 2.1$ & $84.1 \pm 1.6$ & $89.6 \pm 2.1$ & $1.30 \pm 0.1$ & $21.2 \pm 1.9$ & $44.8 \pm 1.2$ & $33.8 \pm 1.1$ \\
\hline & 4 weeks & $86.5 \pm 3.9$ & $83.6 \pm 3.1$ & $88.2 \pm 0.6$ & $1.34 \pm 0.1$ & $23.1 \pm 1.1$ & $42.9 \pm 1.4$ & $32.1 \pm 1.1$ \\
\hline & 8 weeks & $85.8 \pm 4.5$ & $82.9 \pm 2.2$ & $76.3 \pm 1.2^{*}$ & $1.41 \pm 0.1$ & $22.1 \pm 0.8$ & $41.5 \pm 1.1$ & $31.3 \pm 0.8$ \\
\hline
\end{tabular}

* Significantly different from zero time at $\mathrm{p}<0.05$

\section{In vivo antioxidant activity}

Forty two adult male albino rats were divided into seven groups, each of six animals, First group: received $1 \mathrm{~mL}$ saline and kept as a negative control. Diabetes was induced in the other groups using a single dose of intraperitoneal injection of $150 \mathrm{mg} / \mathrm{kg}$ b.wt. alloxan, followed by an overnight fast. Second group: diabetic rats that kept untreated (positive control). From third to sixth groups diabetic rats received $100 \mathrm{mg} / \mathrm{kg}$. bwt of TEE, PEE, ChE\& EAE respectively. Seventh group: diabetic rats that received $7.5 \mathrm{mg} / \mathrm{kg}$ of vitamin $\mathrm{E}$ as a reference drug. The rats received the extracts and the standard drug for seven days. At the end of the experiment, blood glutathione was estimated using biodiagnostic kits (Uma et al. 2013), the results are listed in Table IV.

TABLE (IV) - Results of in vivo antioxidant activity of different extract of $A$. fraxinifolius and vitamin $\mathrm{E}$ drug in male albino rats $(n=6)$

\begin{tabular}{lccc} 
Groups & Blood glutathione $\mathbf{( m g \% )}$ & $\begin{array}{c}\text { \% change from } \\
\text { diabetic control }\end{array}$ & \%Potency \\
\hline Control (1 mL saline) & $36.7 \pm 1.4$ & ----- & ---- \\
Diabetic control & $21.8 \pm 0.5^{*}$ & ----- & ---- \\
Diabetic + TEE $(100 \mathrm{mg} / \mathrm{kg})$ & $35.6 \pm 1.2^{*}$ & 63.30 & 94.51 \\
Diab. + PEE. $(100 \mathrm{mg} / \mathrm{kg})$ & $32.5 \pm 1.3^{*}$ & 49.08 & 73.28 \\
Diab. + ChE. $(100 \mathrm{mg} / \mathrm{kg})$ & $31.4 \pm 0.9^{*}$ & 44.04 & 65.76 \\
Diab. + EAE $(100 \mathrm{mg} / \mathrm{kg})$ & $35.1 \pm 1.1^{*}$ & 61.00 & 91.08 \\
Diabetic +Vitamin E $(7.5 \mathrm{mg} / \mathrm{kg})$ & $36.4 \pm 1.5^{*}$ & 66.97 & 100 \\
\hline
\end{tabular}

* Significantly different from zero time at $\mathrm{p}<0.05$

TEE: Total ethanol extract, PEE: petrolium ether extract; ChE: chloroform extract; EAE: ethyl acetate extract 


\section{Determination of acute anti-inflammatory}

Paw swelling, is a convenient method for assessing inflammatory responses to antigenic challenges and irritants. This effect was determined according and as reported (Abou Zeid et al., 2015). This model uses carrageenan as the irritant to induce paw edema. The test materials are assessed for acute anti-inflammatory activity by examining their ability to reduce or prevent the development of carrageenan-induced paw swelling. Thirty six male albino rats weighing $130-150 \mathrm{~g}$ were divided into six groups, each of six animals, first group received $1 \mathrm{~mL}$ of saline serving as control, second to fifth group received $100 \mathrm{mg} / \mathrm{kg}$ of daily dose TEE, PEE, ChE, EAE extracts respectively. The sixth group received $20 \mathrm{mg} / \mathrm{kg}$ of the reference drug indomethacin.
One hour after oral administration of the extracts, all animals were given a sub plantar injection of $0.1 \mathrm{~mL}$ of $1 \%$ carrageenan solution in saline in the right hind paw and $0.1 \mathrm{~mL}$ saline in the left hind paw. The edema diameter was measured by the caliber at 1, 2, 3, 4 hours after extract administration and \% edema was calculated and results are listed in Table $\mathrm{V}$

$$
\% \text { Edema }=\frac{(w t . \text { of right paw }- \text { wt. of left paw) }}{\text { wt. Of left paw }} \times 100
$$

$\%$ Edema inhibition $=(\underline{M c-M t}) \times 100$

$\mathrm{Mc}$

$\mathrm{Mc}=$ the mean $\%$ edema in the control group

$\mathrm{Mt}=$ the mean $\%$ edema in the drug-treated group

\begin{tabular}{|c|c|c|c|c|c|c|c|c|c|}
\hline & \multirow{2}{*}{ 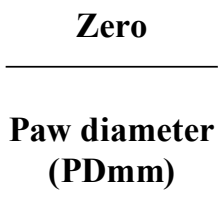 } & \multicolumn{2}{|c|}{1} & \multicolumn{2}{|l|}{2} & \multicolumn{2}{|l|}{3} & \multicolumn{2}{|c|}{4} \\
\hline & & $\begin{array}{c}\mathrm{PD}(\mathrm{mm}) \\
\text { mean } \pm \text { SD }\end{array}$ & $\begin{array}{c}\text { Oedema } \\
\text { thickness } \\
\text { (Oth.mm) }\end{array}$ & $\begin{array}{c}\mathrm{PD}(\mathrm{mm}) \\
\text { mean } \pm \text { SD }\end{array}$ & Oth.mm & $\begin{array}{c}\mathrm{PD}(\mathrm{mm}) \\
\text { mean } \pm \mathrm{SD}\end{array}$ & Oth.mm & $\begin{array}{c}\mathrm{PD}(\mathrm{mm}) \\
\operatorname{mean} \pm \mathrm{SD}\end{array}$ & Oth.mm \\
\hline Control & $3.38 \pm 0.09$ & $4.41 \pm 0.1^{*}$ & 1.03 & $4.81 \pm 0.13^{*}$ & 1.43 & $4.89 \pm 0.12^{*}$ & 1.51 & $4.96 \pm 0.08^{*}$ & 1.58 \\
\hline TEE & $3.42 \pm 0.05$ & $4.34 \pm 0.09^{*}$ & 0.92 & $4.13 \pm 0.06^{*}$ & 0.71 & $3.97 \pm 0.04$ & 0.55 & $3.81 \pm 0.08^{*}$ & 0.39 \\
\hline PEE & $3.45 \pm 0.6$ & $4.31 \pm 0.12^{*}$ & 0.86 & $4.19 \pm 0.1^{*}$ & 0.74 & $4.11 \pm 0.12 *$ & 0.66 & $4.03 \pm 0.07^{*}$ & 0.58 \\
\hline ChE. & $3.46 \pm 0.08$ & $4.29 \pm 0.1^{*}$ & 0.83 & $4.23 \pm 0.07^{*}$ & 0.77 & $4.28 \pm 0.1^{*}$ & 0.72 & $4.24 \pm 0.07^{*}$ & 0.78 \\
\hline EAE & $3.33 \pm 0.1$ & $4.29 \pm 0.1^{*}$ & 0.96 & $4.07 \pm 0.14 *$ & 0.74 & $3.94 \pm 0.09 *$ & 0.61 & $3.79 \pm .0 .04^{*}$ & 0.46 \\
\hline $\begin{array}{l}\text { Indomet- } \\
\text { hacin }\end{array}$ & $3.56 \pm 0.08$ & $4.26 \pm 0.09^{*}$ & 0.72 & $3.99 \pm 0.06^{*}$ & 0.43 & $3.92 \pm 0.01 *$ & 0.36 & $3.83 \pm 0.01^{*}$ & 0.27 \\
\hline
\end{tabular}

TABLE V - Acute anti-inflammatory activity of the TEE extract and sucessive extracts of $A$. fraxinifolius bark

* statistically significant different from control group at $\mathrm{p}<0.01$

\section{RESULTS AND DISCUSSION}

\section{Phytochemical study}

Phytochemical screening of the $A$. fraxinifolius bark revealed that the extracts prepared with polar solvents being rich in carbohydrates, flavonoides and tannins. Sterols and/or triterpenes were present in the extracts prepared with non-polar solvents.
The total phenolic and total flavonoid contents in the TEE extract were found to be $61.06 \pm 0.08 \mu \mathrm{g}$ eq GA/g extract, $40.33 \pm 0.20 \mu \mathrm{g}$ eq $\mathrm{CE} / \mathrm{g}$ extract respectively. Chromatoghraphic isolation of major compounds from EAE (bioactive extract) of $A$. fraxinifolius led to the identification of five phenolic acids and eight flavonoidal compounds from the dried bark of the plant they are: $p$-hydroxybenzoic, p-coumaric acid, protochatchuic, sinapic, cinnamic; flavonoids: apigenin -7-O- $\beta$ - 
glucopyranoside, rutin, catechin, kaempferol, quercetin, chyrsin, myrcetin and luteolin. The identification was carried out through $\mathrm{R}_{\mathrm{f}}$ values, color reactions, chemical investigations (complete acid hydrolysis) and spectral investigations (UV, NMR, MS). (Mabry et al., 1970; Markham 1982; Agrawal 1989) Spectral data of the known flavonoids were in good accordance with those previously published (Markham, Geiger 1994). All these compounds were isolated for the first time from the plant bark.

\section{Biological study: Acute toxicity test}

$\mathrm{LD}_{50}$ of the total ethanol was found to be $7.1 \mathrm{~g} / \mathrm{kg} \mathrm{b}$. $\mathrm{wt}$, this means that the plant is safe to be used in animal experiments and could be later used by humans after carrying clinical trials.

Comparison of organ weights between treated and control group of animals have conventionally been used to evaluate the toxic or adverse effects of test articles or drugs (Peters, Boyd 1966; Pfeiffer 1968).

\section{Chronic toxicity test}

Change in organ and body weight is also used as an assessment of therapeutic response to drugs (Winder 1969). The body and organ weights of experimental animals did not show any significant changes after administration of the ethanol extract for 8 weeks compared to the control groups (Table I and II). In this study the plant extract did not have any adverse effects on experimental animals that would cause them to lose appetite (El-Sanusi and ElAdam et al., 2007), or causing a decrease in food intake and consequently a reduction in weight with an increase in dose. Assay of biochemical parameters was performed to evaluate the liver, renal, lipid and glycemic profiles of experimental compared to the control animals, in order to give insight into pathological changes and nature of disease. In this study, assay of the liver profile parameters (AST, ALT) revealed the normal functioning of the liver after 8 weeks of administration of the aqueous extract, with reduced to normal values in experimental animals when compared to the controls.

The renal profile parameters creatinine and urea remain normal values suggest that the extract does not produce any sort of disturbance in the renal function.

The lipid profile parameters (TGY, CHOL) are indications that the extract did not exert any risk of hypercholesterolemia or atherosclerosis at low doses. The activities of AST, ALT, and the levels of urea, uric acid and creatinine showed that the function of the liver, heart and kidney are not affected by the oral supplementation of extract, Table III.

\section{Antioxidant activity: In vitro antioxidants}

DPPH It is evident that the radical scavenging activity ofDPPHinhibition was $60.31 \%$ at concentration of $50 \mu \mathrm{g} / \mathrm{mL}$ for the TEE of $A$. fraxinifolius bark.

FRAP: The ferric reducing ability of TEE of A. fraxinifolius bark as expressed FRAP values was $55.024 \mu \mathrm{mol}$ Trolox/100 g dry weight, thus the extract showed FRAP ability.

ABTS: The extract expressed $\mathrm{ABTS}^{+}$activity $67.217 \mu \mathrm{mol}$ Trolox/100 g dry weight.

\section{In vivo antioxidant}

From Table IV it was concluded that $100 \mathrm{mg}$ of the TEE followed by $100 \mathrm{mg}$ of EAE exhibited the highest antioxidant activity as shown from the $\%$ of change of glutathione level from diabetic control (63.3 and 61.00\% respectively).

Glutathione (GSH) is a natural antioxidant in the body, a lack of GSH exposes the body to the damaging effects of free radicals, thus speeding up the oxidation process. The diabetogenic process appears to be caused by immune destruction of the $\beta$ cells; part of this process is apparently mediated by production of ROS. Diabetes can be produced in animals by the drugs such as alloxan which result in the production of ROS.(Oberley 1988). A simultaneous fall in blood GSH was observed following the injection of diabetogenic doses of alloxan in rabbits (Leech, Bailey 1945). The significant antioxidant activity of the EAE may be due to the presence of flavonoids (Hanasaki et al., 1994), such as quercetin that increases the level and the activity of GSH in mice (Molina 2003), it also has the ability to scavenge highly reactive species such as peroxynitrite and the hydroxyl radical (Boots et al., 2008). Catechin and other phenolic acids isolated from the plant extract were reported for their antioxidant activity (Yoshinori Kadoma, Seiichiro Fujisawa 2008).

\section{In vivo anti-inflammatory activity}

All extracts exhibited anti-inflammatory activities as indicated by inhibition of the rat paw edema weight 
induced by carrageenan. The highest activity exhibited by $100 \mathrm{mg}$ of the TEE \& EAE $3.81 \pm 0.08$ and $3.79 \pm .0 .04$ respectively, in comparison with indomethacin $3.83 \pm 0.01$ edema diameter as measured by the caliber after 4 hours of extract administration (Table V). Inflammation is part of the complex biological response to harmful stimuli. Pain, heat, redness, swelling, and loss of function are the primary sign of acute inflammation. The inflammation process involves activation of a complex enzyme systems mediator release, fluid extra vasations, cell migration, tissue breakdown and repair which are aimed at host defense and usually activated in most disease conditions (Turner, 1965; Vane, Botting 1995). The highest activity exhibited by TEE \& EAE may be due to the presence of phenolic compounds in both extracts in addition to the nonpolar compounds in the TEE as reported (El-Rafie et al 2020).

\section{CONCLUSION}

Five phenolic acids and eight flavonoid compounds were isolated and identified for the first time from the bioactive EAE of $A$. fraxinifolius bark they were, phenolic acids: $p$-hydroxy benzoic, $p$-coumaric, protochatchuic, sinapic, cinnamic; flavonoids: apigenin -7-O- $\beta$-glucopyranoside, rutin, catechin, kaempferol, quercetin, chyrsin, myrcetin and luteolin. The TEE did not show any signs of acute and chronic toxicity. The encouraging results conducted with the various in vitro antioxidant along with in vivo antioxidant and anti-inflammatory activities of TEE \& EAE guide us towards the possible use of the plant as safe free radical scavenger and anti-inflammatory agent.

\section{ACKNOWLEDGEMENT}

This study is a part of internal project funded by the National Research Centre (NRC) Dokki- Giza Egypt. N0 10010009. Special appreciation is extended to NRC for offering the facilities for this study.

\section{REFERENCES}

Abou Zeid AH, Soliman FM, Mohammed RS, Sleem AA, El Dakrory YM. Galloyle derivatives and biological activities of Acrocarpus fraxinifolius weight and Arn leaves. Planta Medica. 2012;78 PL.213.
Abou Zeid AH Mohammed RS, Sleem A A. Biologically Active Polysaccharides from Grewia asiatica Linn. Leaves. IJPPR Research. 2015;7(5):1080-1087.

Abou Zeid AH, El-Kashoury EA, Sleem AA and Waly DA.Lipoidal Content and Anti-inflammatory Activity of Adenanthera pavonina L.Leaves.JASR. 2012;8(1):207-214.

Abou Zeid AH, Soliman FM, Mohammed RS, Sleem AA, El Dakrory YM. Anti-inflammatory effect and lipoidal content of Acrocarpus fraxinifolius Wight \& Arn leaves. Planta medica. 2011;77, PL8.

Agrawal PK. Carbone-13 NMR of flavonoids. Elservie Science Publishing Co. Inc., New York.1989.

Allian CC, Poon LS, Chan CSG, Richmond, W, Fu, PC. Enzymatic determination of total serum cholesterol. Clin Chem. 1974;20(4):470-475.

Bardia R, Rao JT. Protein seeds of Acrocarpus fraxinifolius. $\mathrm{J}$ of the Inst of Cem. (India). 2004a;76(5):165-166.

Bardia R, Rao JT. Analysis of seeds of Acrocarpus fraxinifolius Wight \& Arn.” J Inst Chem. (India). 2004b;76(5):167-169.

Bardia R, Singh R DK, Rao, JT. Flavone glycoside from seeds of Acrocarpus fraxinifolius Wight \& Arn. J Inst Chem. (India). 2005;77:141-143.

Ebrahimzadeh MA, Nabavi SM, Nabavi SF, Eslamim B. The free radical scavenging ability of methanolic extract of Hyoscyamus squarrosus leaves. Pharmacologyonline. 2009b;2:796-802.

El-Kashak WA, Hamed AR, El-Raey M, Elshamy AI, AbdEllatefGEF. Antiproliferative, antioxidant and antimicrobial activities of phenolic compounds from Acrocarpus fraxinifolius. J Chem Pharm Res. 2016;8(3):520-528.

El-Nashar Heba AS, Omayma A. Eldahshan, Omama E. Elshawi, Abdel Nasser B. Singab. Phytochemical Investigation, Antitumor Activity, and Hepatoprotective Effects of Acrocarpus fraxinifolius Leaf Extract. Drug Dev Res. 2017;78(5):210-226.

El -Rafe H M., Mohammed RS., Abou Zeid A H., Sleem AA. Bioactivities and Phytochemical Studies of Acrocarpus fraxinifolius Bark Wight Arn. Egypt.J.Chem. 2020; 63(1): $203-214$.

El-Sanusi NI, El-Adam S. The effect of low levels of dietary Ruta graveolens and Solenostemma Argel or their mixture on bovans chicks. Asian J Anim Vet Adv. 2007;2(1):27-31. 
Hanasaki Y, Ogawa S, Fukui S. The correlation between active oxygen scavenging and antioxidative effects of flavonoids. Free Radical Biol. Med. 1994;16(6):845-850.

Kadoma Y, Fujisawa S. A comparative study of the radicalscavenging activity of the phenolcarboxylic acids caffeic acid, p-coumaric acid, chlorogenic acid and ferulic acid, with or without 2-mercaptoethanol, a thiol, using the induction period method.Molecules. 2008;13(10):2488-2499.

Kühnau J. The flavonoids: A class of semi-essential food components: Their role in human nutrition. World Review of Nutrition and Dietetics. 1976; 24:117-191.

Leech RS, Bailey CC. Blood alloxan and blood glutathione in rabbits injected with alloxan. J. Bio Chem. 1945;157:525-542.

Mabry TJ, Markham, KR, Thomas MB. The Systematic identification of flavonoids" Springer Verlag, Berlin 1970.

Markham KR, Geiger H. 1H-NMR spectroscopy of flavonoids and their glycosides in hexadeuterodimethylsulfoxide. In: Harborne JB (Ed.), The Flavonoids, Advances in Research since 1986. Chapman and Hall, London, pp: 1994, 441-497.

Markham KR. Technique for flavonoids identification. London: Academic Press; 1982.

Martha Rosales-Castro, Amador Honorato-Salazar J, Guadalupe Reyes-Navarrete Ma, Rubén F. GonzálezLaredo. Antioxidant phenolic compounds of ethanolic and aqueous extracts from pink cedar Acrocarpus Fraxinifolius whight \& arn. Bark at two tree ages. J. Wood Chem Technol. 2015;35(4):270-279.

Mohammed RS, Abou Zeid AH, El-Kashoury EA, Sleem AA, Waly DA. A new flavonol glycoside and biological activities of Adenanthera pavonina L. Leaves. Natural Product Research. 2014;28(5):282-289.

Molina MF, Sanchez-Reus I, Iglesias I, Benedi J.Quercetin A Flavonoid Antioxidant, Prevents and Protects Against Ethanol-induced Oxidative Stress in Mouse Liver. Biol. Pharm. Bull. 2003;26(10):1398-1402.

Nabavi SM, Ebrahimzadeh MA, Nabavi SF, Jafari M. Free radical scavenging activity and antioxidant capacity of Eryngium caucasicum Trautv and Froriepia subpinnata. Pharmacologyonline. 2008;3:19-25.

Negi, S.S. Indian Trees and Their Silviculture. vol I. Legumes; Bishen Singh Mahendra Pal Singh: Dehra Dun, India.2000.

Oberley LW. Free radical and diabetes. Free Radic Bio Med. 1988;5(2):113-124.
Orrenius S, Gogvadze V, Zhivotovsky B. Mitochondrial oxidative stress: Implications for cell death. Annual Review of Pharmacology and Toxicology. 2007;47:143-183.

Paget GE, Barnes JM. Toxicity tests in evaluation of drug activities pharmacometries (Laurence, D. R. and Bacharach, A. L. eds). Academic Press, London and New York, 1964.

Peters JM, Boyd EM. Organ weights and water levels of the rat following reduced food intake. J Nutr. 1966 Dec;90(4):354360 .

Pfeiffer CJ. A mathematical evaluation of the thymic weight parameter. Toxicol Appl Pharmacol. 1968;13(2):220-227.

Suganya T, Siriporn O, Sombat C. Study on antioxidant activity of certain plants in Thailand: Mechanism of antioxidant action of Guava leaf extract. Food Chem. 2007;103(2):381-388.

Tezcan F, Kolayl S, Sahin H, Ulusoy E, Erim BF. Evaluation of organic acid, saccharide composition and antioxidant properties of some authentic Turkish honeys. J. Food Nutr. Res. 2011;50(1):33-40.

Turner RA. Screening Methods in Pharmacology. Vol. 1, New York: Academic Press. 1965;152-160.

Uma M, Suresh M, Thulasiraman K, Lakshmidevi E, Kalaiselvi P. Chronic toxicity studies of aqueous leaf extract of Indian traditional medicine plant Ocimum tenuiflorum (Linn.) in rats. European Journal of Experimental Biology. 2013;3(5):240-247.

Vane JR, Botting RM. New insights into the mode of action of anti-inflammatory drugs. Inflamm. Res. 1995;44(1):1-10.

Vázquez, G, Antorrena G, Parajó JC. Studies on the utilization of Pinus pinaster bark. Wood Sci Technol., 1987;21(1):65-74.

Winder CV., Lembke LA, Stephens MD. Comparative bioassay of drugs in adjuvant-induced arthritis in rats: flufenamic acid, mefenamic acid and phenylbutazone. Arthritis \& Rheumatasim. 1969;12(5):472-482.

Zhong J. IR study of galactomannans. Guangpuxue YuGuangpu Fenxi 1985;5:42-43.

Received for publication on $14^{\text {th }}$ April 2018 Accepted for publication on $13^{\text {rd }}$ February 2019 